\title{
A BRIEF ANALYSIS ON DIVIDEND PUZZLE BASED ON BEHAVIORAL PORTFOLIO THEORY
}

\author{
Guosong Wang \\ School of Economics,Shanghai University, P.R.China \\ Keqi Zhang \\ School of Economics,Shanghai University, P.R.China
}

\begin{abstract}
Dividend puzzle is the phenomenon that private investors take dividends and capital gains as two things and like dividends more. This problem was once a difficult problem of behavioral finance. However, with continuous development of traditional financial theory, dividend puzzle explicated by related theory. This paper is based on behavioral finance theory to explore the reasons for the dividend puzzle, and compare and elaborate the current dividend and equity repurchase trend.
\end{abstract}

Keywords: Dividend Puzzle, BPT-SA, BPT-MA

\section{JEL code: G14}

In China, dividend distribution has five ways generally as follows: cash dividends, stock dividends, liability dividends, property dividends and equity repurchase, and the first two are the most common way.Shefrin and Statman (2000) proposed the Behavioral Portfolio Theory(BPT) according to Markowitz's Modern Portfolio Theory, BPT paid more attention to the specific investment behavior of investors, which can not only explain anomalies in the market, also be widely used in investment practice. At present, the listed companies of Shanghai and Shenzhen Stock Exchange are more inclined to use the way of cash dividends, so it is significantly important to compare and analyze the cash dividend and stock repurchase. 


\section{Classic theory of dividend puzzle}

In 1958, economists Modigliani and Miller deduced a conclusion in the context of strict assumptions about capital markets and corporate finance:in the effective financial market, the firm's value is determined by the actual profitability of its assets and has nothing to do with the specific financing methods as well as the capital structure and the structure of circulation right segmentation.In the absence of transaction friction and tax market,also under the same conditions of the debtor and creditor, companies and individuals can use risk-free interest rate to debit and credit unlimitedly,so MM theory believed that the company's decision-making program of dividend distribution and capital structure do not affect company's value, so the company can choose to pay dividends can also choose not to send.

Economists Modigliani and Miller (1963) argued that debt financing has no effect on performance of firm after taking taxation factors into account. Investors who are not worried about increasing costs can have their own dividend policy, and investors can sell their stock to earn spreads to create their dividends, and also use the bonus to buy more stocks.

\section{The theory of behavioral finance}

\subsection{Single Account Behavior Portfolio Theory (BPT-SA)}

The investors of single account portfolio theory treat the portfolio as a whole mental account and consider the correlation between assets, that is, the covariance between them. The choice of asset portfolio in this theory is similar to the choice of security portfolio in the mean variance model, but the BPT-SA theory adds the influence of psychological factors to portfolio selection.

In the single account behavior portfolio theory, there are three possible outcomes for its earnings: $0, A$, and $W_{n}$ (above the value of $A$ ). $A$ is the expected level of income, $W_{n}$ is wealth. This distribution of benefits is similar to the distribution of proceeds from a combination between an insurance for A or 0 and a lottery for $\mathrm{W}_{\mathrm{n}}$.

In the single account behavior portfolio theory, the risk is determined by a number of factors. The choice of the final target asset portfolio is influenced by five risk measurement parameters: the measurement of fear, the measurement of hope, the expectation of wealth level, the relative degree of fear and hope, the degree of desire to earn a expected gain under 
fear and hope.

\subsection{Multiple Account Behavior Portfolio Theory (BPT-MA)}

Multiple Account Behavior Assets Theory assumes that investors have two psychological accounts, one is a high-expectation mental account that represents a willingness to seek high returns, and a low-expectation mental account that represents a willingness to seek a stable condition without risk. The investors are committed to distribute existing wealth into two different psychological accounts, which achieves the maximum of overall utility. Traditional investors believe that they should focus on the entire portfolio rather than the gains and risks of individual assets, which needs considerate the correlation between assets. But in reality, many investors will not follow this behavior, they actually build the portfolio like a pyramid, the greater gains, the more risk from the bottom of the pyramid to the top, the expected level is also increasing by layer, the investment of the bottom is the most security quality and also has relatively low-yield,and the underlying level of assets is linked to specific risks and benefits.

Assuming that the utility function of the high expectation mental account is the Douglas Function: $U_{\mathrm{H}}=P_{H}^{1-\gamma} E_{\mathrm{h}}(W)^{\gamma}$, where $P_{H}$ is the probability of unreaching the high expected level, $E_{h}(W)$ is the mean total wealth of the investor, $\gamma$ is a nonnegative weight parameter; In the same way, the utility function of the lower-expected mental account: $U_{L}=P_{L}^{1-\beta} E_{\mathrm{h}}(W)^{\beta}$. Therefore, it can be assumed that the utility function of the investor is the combination of utility function of the high expectation mental account and the low expectation mental account, as follows: $U=\left[1+K_{\mathrm{d} H}\left(P_{H}{ }^{1-\gamma} E_{h}(W)^{\gamma}\right]\left[K_{\mathrm{d} L}\left(P_{L}^{1-\beta} E_{\mathrm{h}}(W)^{\beta}\right)\right]\right.$. From this function, it can be seen that the relationship between individual assets is ignored.

\subsection{Dividend puzzle}

Shefrin and Statman argued that the cash dividend is not equal to the capital gains from selling stocks because each investor has a different choice for high-dividend and low-dividend stocks. For example, some investors who are retired like high-dividend stocks, because such stocks continuous and stable, which can not only alleviate pressure of lacking cash, but also need not to sell their own stock in hands, so the cash dividend and capital gains from selling the stock belong to different mental accounts.

Rational investors know that capital gains and dividends are almost the same, because they do 
not rely on dividends as income, but receive the spread of the stock to get the benefits, especially when the dividend tax more than the capital gains, dividends may have less income than capital gains finally, so investors are supposed to agree that company does not distribute dividends. But in real life, investors are more likely to invest in companies can pay dividends. According to the behavioral portfolio theory, one dollar dividend and one dollar capital gains are different because investors divide them into two completely independent expectations of different mental accounts, that is a low-expectation of low-risk dividend accounts and a high-expectation of high-risk capital gains account. When stock price falls, the investor will feel the loss of the capital account, while they believe the loss of mental accounts when the company is not pay dividends, investors see the dividend account as a stable and secure income, and the capital account as a pursuit of high-yield account.

\section{Cash dividend and stock repurchase}

Assuming that in a tax-free and non-transactional market, cash dividend and stock repurchase should be indistinguishable, but taking the market's non-completeness and information asymmetry into account, the two are not exactly the same. From the shareholder's point of view, dividend policy of the company that can maximize the cash flow value, enhance the company's overall profitability is the best. To the US market for reference, cash dividend and stock repurchase coexist for a long time, and the US market do not have trend to replace each other completely, indicating that the two way are not superior to each other.

\subsection{Comparison of cash dividend and equity repurchase}

First, the psychological effects are different. Cash dividend is seen as ordinary income, while income of stock repurchase is a capital interest to investors. Second, the choice is different. The option to buy equity is more free, and the cash flow generated by the company after repurchasing is finally returned to shareholders who prefer to hold cash rather than ownership.Third, the signal effect is different. When the company believes that cash flow growth is long-term, the company will send more dividends, if that is short-term, then choose stock repurchase. Fourth, the impact on investor's confidence is different. Guohua Jiang et al. (2006) model study showed that investor confidence is positively proportional to the amount of dividends determined by the company, and companies that often profitable are trying to protect the interests of investors to use cash dividend way and then creating a good internal and external environment.

\subsection{The Present distribution of dividend in China}

The data of Shanghai and Shenzhen Stock Exchange showed that a total of more than 100 listed companies of two stock exchange pay dividend in $2013-2015$, which proportioned more than 50\%. According to the 2016 annual report of listed company showed that 174 enterprises had the proportion of dividends more than 50\% in one year, and in 2016, Shanghai 
stock company's overall ratio of paying dividend attached to $31.38 \%$, still the same as in previous years basically. At the same time Shenzhen Stock Exchange showed that up to March 24, 2017,it had already 405 listed companies announced the profit distribution plan, and 343 listed companies paid cash dividends.

In China, many listed companies are state-owned enterprises or restructured state-owned enterprises, and the state-owned shareholders occupy a large proportion. Therefore,they want to maintain their shareholding ratio instead of selling the stock, but they also have cash demand, as well as hope that listed companies pay dividends. Wang, Marry etc. (2011) confirmed this with data from 1998 to 2008 in the china stock market, where state-owned listed companies have a strong preference of dividend and this trend is on the rise.

\section{Conclusion and recommendations}

At present, the listed companies in Shanghai and Shenzhen Stock Exchange have adopted cash dividend policy increasingly, and also this trend has potential to rise, which is appealing to investors' investmental psychology. In the modern era, the dividend puzzle has been well explained, after all, most investors are hoping for more stable returns.

In China, system of current securities market is unsound, and supervision of the environment is imperfect, so China's listed companies do not have to rush to implement stock repurchase policy.From China's current situation, although the listed companies do not have conditions for the general stock repurchase, it has feasibility for listed companies to increase gradually stock repurchase under the background of capital market reform, as far as possible to improve the relevant system.

On the one hand, listed companies should choose their dividend policy according to their own situation, rigorously do the repurchase program, as well as the China Securities Regulatory Commission should also strictly monitor the whole process of stock repurchase; if the company do not carry out stock repurchase within 3 months from the date of the announcement, then it should receive a rigorous review for the record, even cancel the repurchase or enforce the repurchase. On the other hand, for more effective cash dividend policy, it is necessary to speed up the pace of reform, such as directly exempting dividend's taxes, reducing the cost of earnings of investors and encouraging company to allocate stable dividends for a long period of time to raise investmental willingness and confidence , and to reduce the speculative psychology of investors,as well as cultivate habits of long-term holdings of investment,also to further enhance the stock price, and achieve win-win condition of both sides finally. 


\section{References :}

Shefrin,Hersh and Statman,M.(2000) "Behavioral Portfolio Theory", Journal of Financial and Quantitative Analysis,vol. 35, no. 2,pp. 127-151.

Qingfeng Li.(2008) "Research on deepening and expanding based on MM theorem -Does circulation right division influence corporate value", Finance Research,vol.12, pp. 113-125.

Modigliani, F. and Miller,M.(1963)“Corporate income taxes and the cost of capital:a correction ”,American Economic Review, vol. 53, pp. 433-443.

Ling Mou, Jia Chen,and Yindong Huang. (2004)"Behavioral Portfolio Theory: the basic theory, content and interpretation of anomalies". Journal of Nanjing University of Finance and Economics, vol. 04, pp. 41-44.

Jingyang Kan.(2012) "Behavioral finance theory and dividend puzzle", Enterprise reform and management, vol. 07, pp. 15-16.

Guohua Jiang, Xinzhong Xu, Longkai Zhao.(2006)“Study on Corporate Governance and Investor Protection ",Management World,vol. 06, pp. 161-170.

Baochen Zhu. (2017)"174 companies ratio of paying dividend more than $50 \%$ in Shanghai stock market last year”, Securities Daily,vol. 05, no. 05, A02.

Nan Jiang.(2017)"more than 100 companies the proportion of dividends over $50 \%$ for three consecutive years in Shanghai and Shenzhen stock market",Securities Daily,vol. 03, no. 25, A01.

Wang X, Manry D, Wandler S. (2011)“The impact of government ownership on dividend policy in China",Advances in Accounting, vol. 27,no. 02, pp. 366-372.

Qi Lin.(2013)“ investor protection Based on the reform of dividend policy of listed companies 
-- selection of cash dividends and stock repurchase",Journal of Hebei University of Economics and Business, vol. 04, pp. 64-69. 